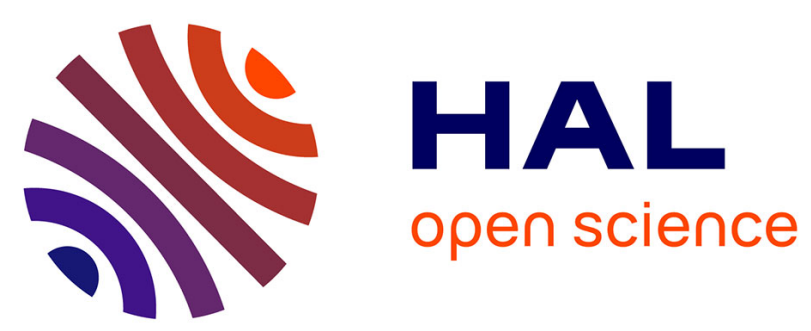

\title{
DEPOSITION OF Y-Ba-Cu-O-FILMS BY MO-CVD USING A NOVEL BARIUM PRECURSOR
}

C. Spee, E.A. van Der Zouwen-Assink, K. Timmer, A. Mackor, H. Meinema

\section{To cite this version:}

C. Spee, E.A. van Der Zouwen-Assink, K. Timmer, A. Mackor, H. Meinema. DEPOSITION OF Y-Ba-Cu-O-FILMS BY MO-CVD USING A NOVEL BARIUM PRECURSOR. Journal de Physique IV Proceedings, 1991, 02 (C2), pp.C2-295-C2-302. 10.1051/jp4:1991236 . jpa-00249825

\section{HAL Id: jpa-00249825 https://hal.science/jpa-00249825}

Submitted on 1 Jan 1991

HAL is a multi-disciplinary open access archive for the deposit and dissemination of scientific research documents, whether they are published or not. The documents may come from teaching and research institutions in France or abroad, or from public or private research centers.
L'archive ouverte pluridisciplinaire HAL, est destinée au dépôt et à la diffusion de documents scientifiques de niveau recherche, publiés ou non, émanant des établissements d'enseignement et de recherche français ou étrangers, des laboratoires publics ou privés. 


\title{
DEPOSITION OF Y-Ba-Cu-O-FILMS BY MO-CVD USING A NOVEL BARIUM PRECURSOR
}

C.I.M.A. SPEE, E.A. VAN DER ZOUWEN-ASSINK, K. TIMMER, A. MACKOR and H.A. MEINEMA

TNO Industrial Research, P.O. BOx 108, NL-3700 AC Zeist, The Netherlands

\begin{abstract}
Y-Ba-Cu-oxides are deposited by MOCVD in a hot-wall reactor using the well known copper- and yttrium- $\mathrm{B}$-diketonate precursors, $\mathrm{Cu}(\text { thd })_{2}$ and $\mathrm{Y}(\text { thd })_{3}$, and the novel barium precursor, $\mathrm{Ba}(\mathrm{hfa})_{2}$-tetraglyme. This novel barium precursor is thermally stable, non-hygroscopic and highly volatile. Depositions are performed on single-crystalline (100)-oriented $\mathrm{MgO}$ substrates. Depositions performed at $800^{\circ} \mathrm{C}$ and $900^{\circ} \mathrm{C}$ show smooth c-axis-oriented $\mathrm{YBa}_{2} \mathrm{Cu}_{3} \mathrm{O}_{7-\delta}$ layers, with $\mathrm{CuO}$ precipitates. At $900^{\circ} \mathrm{C}$ also $\mathrm{Y}_{2} \mathrm{BaCuO}_{5}$ and barium oxide crystals are present.
\end{abstract}

\section{1 - INTRODUCTION}

The deposition of thin films of high- $T_{c}$ superconducting metal oxides has been extensively investigated by several techniques including sputtering, laser ablation, MBE, PVD and CVD /1/. Among these techniques metalorganic chemical vapor deposition (MOCVD), which is well known for the deposition of semiconductor films, ceramic films and oxidic coatings, is a promising technique for the deposition of superconducting layers. MOCVD offers the possibility to deposit layers at high partial pressures of oxygen and to control the growth of oriented or even epitaxial grains. Both are essential for obtaining high $T_{c}$ characteristics of the layers. Moreover homogeneous layers can be deposited on large substrates. Several groups have reported on MOCVD deposition of $\mathrm{Y}$-Ba-Cu-oxide films /2-6/, using metal- $\mathrm{B}$ diketonates as precursors. Generally the low volatility and thermal instability of the alkalineearth metal B-diketonates at evaporation temperatures $>200^{\circ} \mathrm{C}$, required for a sufficient mass transport, appears to be a bottleneck in the development of a practical MOCVD process for high $T_{c}$-superconducting films. Investigations performed at TNO into the development of superior alkaline-earth metal MOCVD precursors has resulted in the finding of a series of thermally stable, non-hygroscopic, highly volatile compounds being complexes of fluorinesubstituted $\mathrm{Ca}$-, $\mathrm{Sr}$ - and $\mathrm{Ba}$ - $\mathrm{B}$-diketonates with neutral (poly)-oxygen and -nitrogen donor ligands /7-8/ Representative compounds of these types appear to be superior MOCVD precursors. $\mathrm{Ba}(\mathrm{hfa})_{2} \cdot$ tetraglyme, $\mathrm{Sr}(\mathrm{hfa})_{2} \cdot$ tetraglyme and $\mathrm{Ca}(\mathrm{hfa})_{2}$ triglyme, recently have been 
successfully applied for the deposition of high $\mathrm{T}_{\mathrm{c}}$ superconducting $\mathrm{Tl}-\mathrm{Ba}-\mathrm{Ca}-\mathrm{Cu}-\mathrm{O} / 9 /$ and $\mathrm{Bi}-$ Sr-Ca-Cu-O /10/ films.

This paper reports on the MOCVD deposition of $\mathrm{Y}-\mathrm{Ba}-\mathrm{Cu}-\mathrm{O}$ films using $\mathrm{Ba}(\mathrm{hfa})_{2}$-tetraglyme as a $\mathrm{Ba}$ precursor.

\section{2 - EXPERIMENTAL}

The novel barium precursor, $\mathrm{Ba}(\mathrm{hfa})_{2}$-tetraglyme, (hfa $=1,1,1,5,5,5$-hexafluoro-2,4-pentanedionate, tetraglyme $=2,5,8,11,14$-pentaoxapentadecane), has been synthesized by the reaction of $\mathrm{Ba}(\mathrm{hfa})_{2}$ with one equivalent of tetraglyme $/ 7 /$. This barium compound is a highly volatile, non-hygroscopic, thermally stable, crystalline solid, $\mathrm{mp} 146^{\circ} \mathrm{C}$. It has been applied in this study, both as a solid, $\mathrm{T}_{\text {evap }}<146^{\circ} \mathrm{C}$, and as a liquid, $\mathrm{T}_{\text {evap }}>146^{\circ} \mathrm{C}$, barium MOCVD precursor. The well known copper and yttrium precursors $\mathrm{Cu}(\text { thd })_{2}$ and $\mathrm{Y}(\text { thd })_{3}$ (thd $=2,2,6,6$-tetramethyl-3,5heptanedionate) have been commercially obtained (STREM Chemicals Inc.). The three MOCVD growth runs described in this article, are three out of a series of thirteen experiments in which the same sample of $\mathrm{Ba}(\mathrm{hfa})_{2}$.tetraglyme has been used. After 13 experiments (9 at an evaporator temperature of $163^{\circ} \mathrm{C}$ and 4 at $147^{\circ} \mathrm{C}$ ), the average evaporation rate was $0.48 \mathrm{gr} / \mathrm{hr}$. The MOCVD equipment, (fig.1), consists of: the gas supply and control system, the evaporators, the mixing chamber, the hot wall reactor and the vacuum system. Nitrogen is used

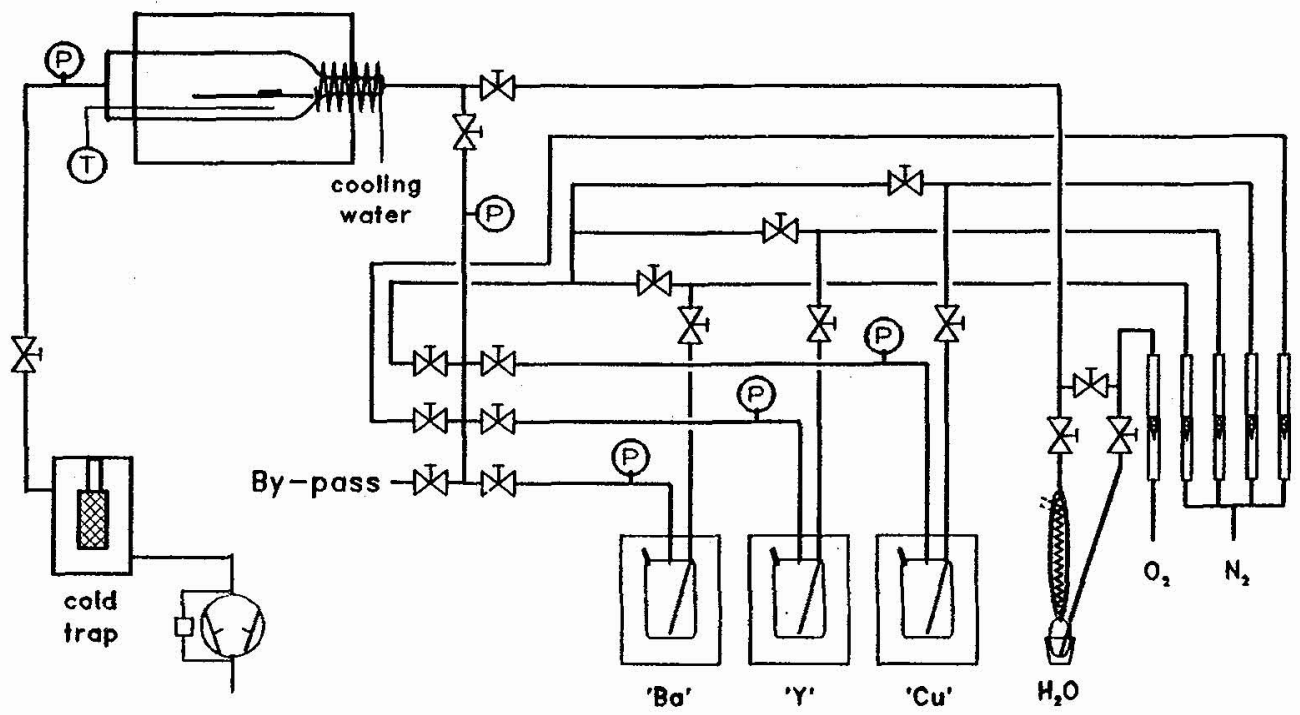

Fig. 1 Schematic diagram of the MOCVD system.

as carrier gas for the precursors and can be introduced into the reactor through a bypass or through the evaporators. Before entering the reactor the gas flows from all three evaporators are combined in a mixing chamber. At the entrance of the furnace, oxygen saturated with water, by passing through a water vaporiser, is added. The evaporators, heated by thermostat baths, are made of glass in order to be able to monitor the performance of the precursors during the experiments. From the evaporators up to the reactor all gas lines, made of stainless 
Table 1. Experimental MOCVD conditions

\begin{tabular}{ll} 
Evaporator temperatures & \\
$\mathrm{Y}(\text { thd })_{3}$ & $: 81-173^{\circ} \mathrm{C}$ \\
$\mathrm{Ba}(\mathrm{hfa})_{2} \cdot$ tetraglyme & $: 111-175^{\circ} \mathrm{C}$ \\
$\mathrm{Cu}(\text { thd })_{2}$ & $: 100-181^{\circ} \mathrm{C}$ \\
Flow through evaporators & $: 5.51 / \mathrm{hr}(\mathrm{STP})$ \\
Total flow through reactor & $: 1001 / \mathrm{hr}(\mathrm{STP})$ \\
$\mathrm{N}_{2}: \mathrm{O}_{2}$ & $: 3: 1$ \\
Pressure in evaporators & $: 4.5 \mathrm{kPa}$ \\
Pressure in reactor & $: 1.6 \mathrm{kPa}$ \\
Substrate temperature & $: 800^{\circ} \mathrm{C}$ \\
\hline
\end{tabular}

steel, are heated by heating tapes at temperatures at least $20^{\circ} \mathrm{C}$ above the temperature of the vaporiser in order to avoid condensation of the precursors. In order to avoid premature decomposition of the precursors in the entrance of the reactor, this part is cooled by water in a copper cooling tube. The substrate temperature is measured underneath the substrate table at the location of the samples.

For each individual precursor, mass transport data has been measured at the conditions presented in table 1 using a mass balance arrangement combined with a vertical hot wall reactor (fig. 2). In this arrangement the substrates (polycrystalline yttrium stabilized zirconia (YSZ)) are attached to a quartz wire which is connected to a mass balance. During deposition the mass changes are recorded.

The experimental conditions for a series of MOCVD experiments are summarized in table 2. For the Y-Ba-Cu-O deposition experiments (100) oriented single-crystalline $\mathrm{MgO}$ substrates were used. After deposition the samples are slowly cooled to room temperature in pure oxygen at atmospheric pressure. Deposited layers have been characterised by XRD, SEM, EDX and

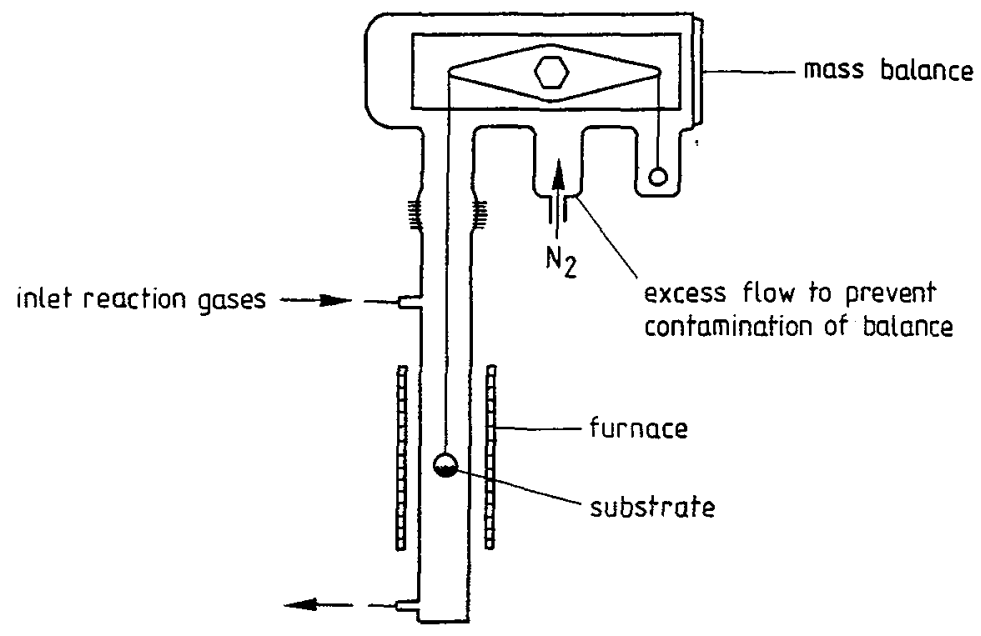

Fig. 2 Schematic diagram of the mass balance arrangement. 
Table 2. Experimental MOCVD conditions

\begin{tabular}{|c|c|c|c|c|c|}
\hline & & $\begin{array}{r}\text { Evaporator } \\
\text { Y(thd })_{3} \\
\mathrm{Ba}(\mathrm{hfa})_{2} \\
\mathrm{Cu}(\text { thd })_{2} \\
\text { Flow throug } \\
\text { Pressure in } \\
\text { Pressure in }\end{array}$ & $\begin{array}{l}\text { mperatures } \\
\text { raglyme } \\
\text { evaporators } \\
\text { aporators } \\
\text { ictor }\end{array}$ & $\begin{array}{l}: 163^{\circ} \mathrm{C} \\
: 147^{\circ} \mathrm{C} \\
: 147^{\circ} \mathrm{C} \\
: 5.51 / \mathrm{hr}(\text { STP }) \\
: 4.5 \mathrm{kPa} \\
: 1.6 \mathrm{kPa}\end{array}$ & \\
\hline Sample & $\begin{array}{c}\text { Total flow } \\
(1 / \mathrm{hr}(\mathrm{STP}))\end{array}$ & $\begin{array}{c}\mathrm{O}_{2} \\
(\mathrm{l} / \mathrm{hr}(\mathrm{STP}))\end{array}$ & $\begin{array}{l}\text { Ratio } \\
\mathrm{N}_{2}: \mathrm{O}_{2}\end{array}$ & $\begin{array}{c}\mathrm{H}_{2} \mathrm{O}_{\text {evaporator }} \\
\left({ }^{\circ} \mathrm{C}\right)\end{array}$ & $\begin{array}{c}\mathrm{T}_{\text {substrate }} \\
\left({ }^{\circ} \mathrm{C}\right)\end{array}$ \\
\hline A & 252 & 126 & $1: 1$ & 50 & 900 \\
\hline B & 252 & 126 & $1: 1$ & 50 & 800 \\
\hline $\mathrm{C}$ & 150 & 75 & $1: 1$ & 60 & 900 \\
\hline
\end{tabular}

XPS. EDX analyses have been performed using an accelerator voltage of $40 \mathrm{kV}$. The quantitative analysis of the MOCVD samples has been achieved by calibration, using analyses results on a number of well-characterised reference samples (e.g. $\mathrm{YBa}_{2} \mathrm{Cu}_{3} \mathrm{O}_{7}$ ).

\section{3 - RESULTS AND DISCUSSION}

For the deposition of $\mathrm{Y}-\mathrm{Ba}$-Cu-oxides with an $\mathrm{Y}: \mathrm{Ba}: \mathrm{Cu}$ ralio of 1:2:3, it is necessary to know the independent mass transport rates of the individual $\mathrm{Y}, \mathrm{Ba}$ and $\mathrm{Cu}$ precursors. These rates have been determined by measuring the growth rate of $\mathrm{Y}$ - and $\mathrm{Cu}$-oxides and Ba-fluorides, from the precursors $\mathrm{Y}(\text { thd })_{3}, \mathrm{Cu}(\text { thd })_{2}$ and $\mathrm{Ba}(\mathrm{hfa})_{2}$.tetraglyme, versus the evaporation temperature, in a combined mass balance-MOCVD apparatus. The results of these measurements are presented in fig. 3. XRD analyses showed the deposits to be respectively $\mathrm{Y}_{2} \mathrm{O}_{3}$, a mixture of approximately 2:1 $\mathrm{Cu}_{2} \mathrm{O}$ and $\mathrm{CuO}$, and $\mathrm{BaF}_{2}$. The novel Ba-precursor $\mathrm{Ba}$ (hfa) $)_{2}$ tetraglyme appears to posses a volatility comparable to that of $\mathrm{Cu}(\text { thd })_{2}$, whereas $\mathrm{Y}(\mathrm{thd})_{3}$ is the least volatile. The dependence of the mass transport with evaporation temperature is for both $\mathrm{Cu}(\text { thd })_{2}\left(\mathrm{E}_{\mathrm{a}}=105 \mathrm{~kJ} / \mathrm{mol}\right)$ and $\mathrm{Ba}(\mathrm{hfa})_{2}$.tetraglyme $\left(\mathrm{E}_{\mathrm{a}}=90 \mathrm{~kJ} / \mathrm{mol}\right)$ relatively large as compared to $\mathrm{Y}(\mathrm{thd})_{3}\left(\mathrm{E}_{\mathrm{a}}=65 \mathrm{~kJ} / \mathrm{mol}\right)$.

A series of experiments has been performed aiming at the deposition of $\mathrm{Y}-\mathrm{Ba}-\mathrm{Cu}-\mathrm{O}$ layers. For the representative experiments A, B and C (see Experimental), a series of analysis results on the MOCVD deposited coatings is given in table 3. The overall ratio of $\mathrm{Y}: \mathrm{Ba}: \mathrm{Cu}$ in the deposited coatings, measured by EDX, differs drastically between the samples A, B and C. More elaborate studies /13/ have shown that the deposition profile in the horizontal hot-wall reactor is different for each of the three precursors, $\mathrm{Y}(\mathrm{thd})_{3}, \mathrm{Ba}(\mathrm{hfa})_{2}$.tetraglyme and $\mathrm{Cu}$ (thd) $)_{2}$. The shape of the deposition profile is influenced by the deposition temperature, the total flow 


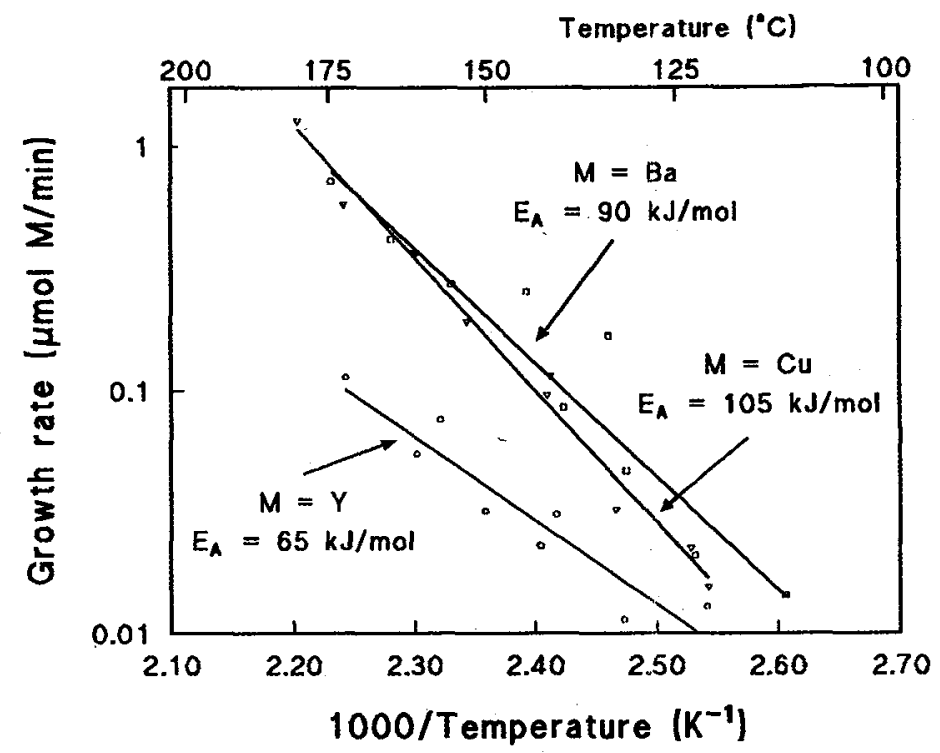

Fig. 3 Normalised mass transport measurements. Substrate polycrystalline YSZ.

Table 3 Analysis of MOCVD deposits.

\begin{tabular}{ccccc}
\hline Sample & $\begin{array}{c}\dot{\mathbf{Y}}: \text { Ba : Cu ratio } \\
\text { (overall) }\end{array}$ & $\begin{array}{c}\text { Layer thickness } \\
(\mathrm{nm})\end{array}$ & $\begin{array}{c}\text { Deposition rate } \\
\mathrm{nm} / \mathrm{min}\end{array}$ & $\begin{array}{c}\mathbf{R}^{*} \\
(\mathrm{k} \Omega)\end{array}$ \\
\hline A & $1.26: 1.50: 3.24$ & 450 & 7.5 & 0.9 \\
B & $0.71: 1.32: 3.97$ & 400 & 6.7 & 0.5 \\
C & $0.99: 0.92: 4.10$ & 780 & 13.0 & 3 \\
\hline
\end{tabular}

* Measured at room temperature.

rate, the partial pressure of oxygen and water, etc. In order to compensate for these effects, evaporation temperatures had to be adjusted. The precursors decompose completely in the reactor. This is in good agreement with the observation of Schmaderer et al. /2/ who have shown that at deposition temperatures $T_{s}>600^{\circ} \mathrm{C}$ the deposition is limited by mass transport of reactive species towards the substrate surface.

Scanning Electron Microscope (SEM) micrographs of the Y-Ba-Cu-oxide layers A, B and C deposited on (100) $\mathrm{MgO}$, together with the results of the EDX spot and overall analysis of these layers, are presented in figures $4 \mathrm{~A}, \mathrm{~B}$ and $\mathrm{C}$. The matrix of the layers A, B and C has been analysed by EDX to have an approximate $\mathrm{Y}: \mathrm{Ba}: \mathrm{Cu}$ ratio of 1:2:3. The surface structure of the layers deposited at 800 and $900^{\circ} \mathrm{C}$ is markedly different. The layer deposited at $800^{\circ} \mathrm{C}$ (B), shows a surface with large, approximately $1 \mu \mathrm{m}$, precipitates, which has been found to be 

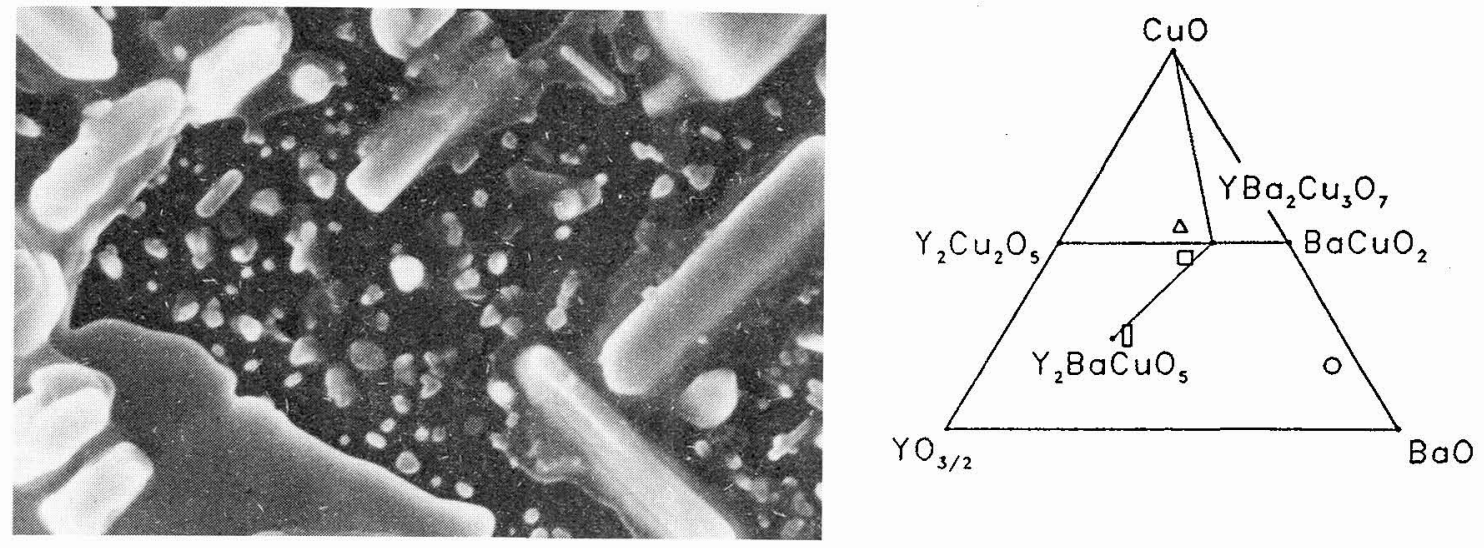

Sample A

\section{$\sqrt{3 \mu \mathrm{m}}$}
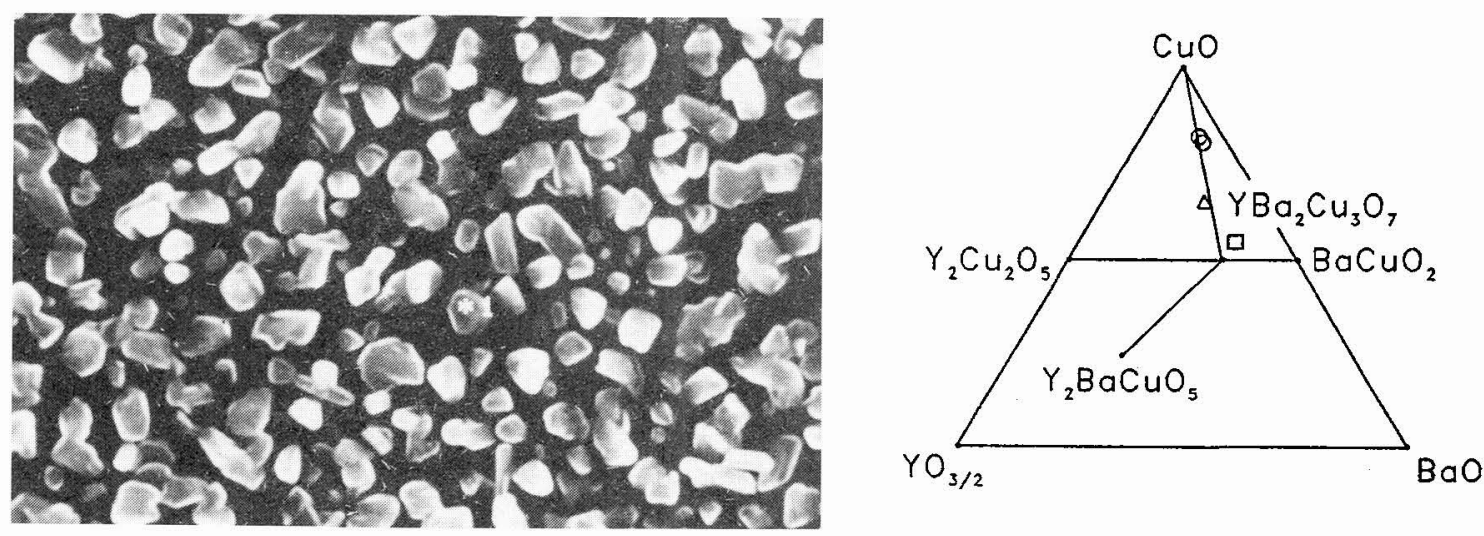

\section{Sample B}
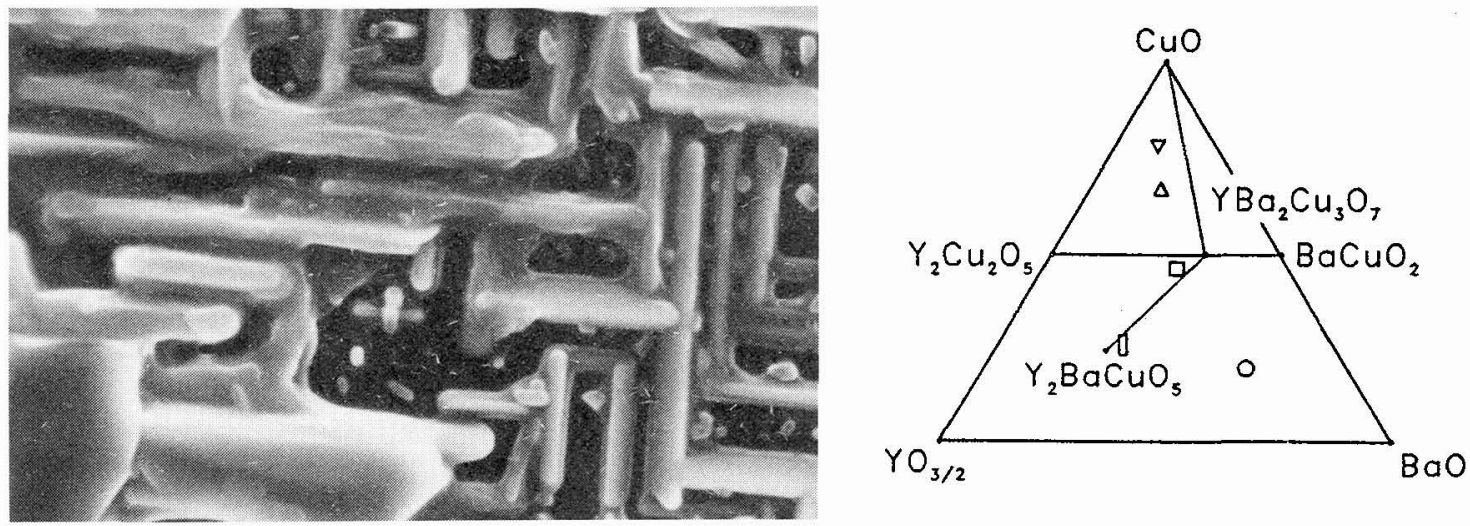

Sample C

$3 \mu \mathrm{m}$

Fig. 4 SEM micrographs and phase diagrams with EDX analysis of $\mathrm{Y}: \mathrm{Ba}: \mathrm{Cu}$ ratio in overall and spot analysis. $\Delta$ overall analysis $\square$ matrix $\circ$ round precipitate Dneedle-like crystals $\nabla$ large plaques. 
$\mathrm{CuO}$. The layers deposited at $900^{\circ} \mathrm{C}$ ( $\mathrm{A}$ and $\mathrm{C}$ ) show round crystals which are $\mathrm{Ba}$ rich, and large plaque like structures which are copper rich. The surface also contains needle-like crystals of $\mathrm{Y}_{2} \mathrm{BaCuO}_{5}$, likely to be formed in reactions with water, present during the deposition for the 'in-situ' conversion of barium fluoride into barium oxide. Yan et al. /12/ propose theconversion of $\mathrm{YBa}_{2} \mathrm{Cu}_{3} \mathrm{O}_{7}$ into $\mathrm{Y}_{2} \mathrm{BaCuO}_{5}$ to occur according to the following equation:

$$
2 \mathrm{YBa}_{2} \mathrm{Cu}_{3} \mathrm{O}_{7}+3 \mathrm{H}_{2} \mathrm{O} \rightarrow \mathrm{Y}_{2} \mathrm{BaCuO}_{5}+3 \mathrm{Ba}(\mathrm{OH})_{2}+5 \mathrm{CuO}+0.5 \mathrm{O}_{2}
$$

This also explains the presence of Ba-rich crystals which are found on the surfaces of samples $\mathrm{A}$ and $\mathrm{C}$. The X-ray pattern of the film deposited on sample $\mathrm{C}$ is presented in figure 4 . It

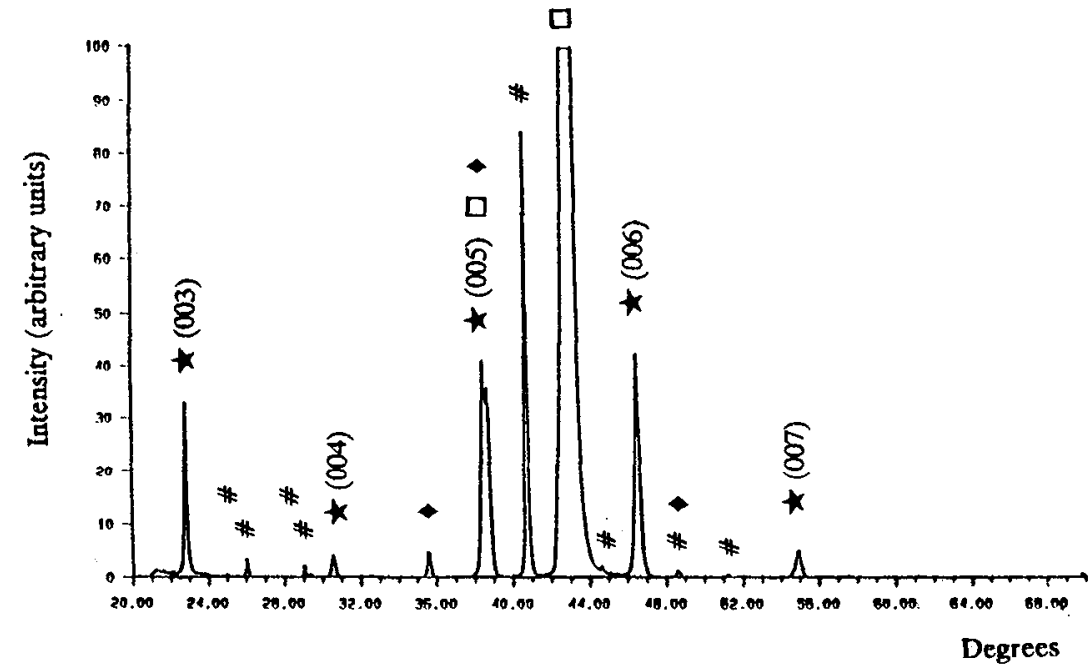

Fig. $5 \quad \mathrm{XRD}$-spectrum of sample C. $\left(\star \mathrm{YBa}_{2} \mathrm{Cu}_{3} \mathrm{O}_{7}\right.$;

\# $\mathrm{Y}_{2} \mathrm{BaCuO}_{5}$; 口 $\mathrm{MgO}$; ・ $\left.\mathrm{CuO}\right)$.

shows the presence of $\mathrm{YBa}_{2} \mathrm{Cu}_{3} \mathrm{O}_{7-\delta}$ with the c-axis oriented perpendicular to the substrate. Poly-crystalline $\mathrm{Y}_{2} \mathrm{BaCuO}_{5}$ and trace amounts of $\mathrm{CuO}$ are also present. The XRD spectrum of $A$ is very similar to that of $\mathrm{C}$, except for $\mathrm{CuO}$ peaks which are absent. The XRD spectrum of $\mathrm{B}$ only shows peaks from c-axis-oriented $\mathrm{YBa}_{2} \mathrm{Cu}_{3} \mathrm{O}_{x}$, and trace amounts of $\mathrm{CuO}$, whereas $\mathrm{Y}_{2} \mathrm{BaCuO}_{5}$ appears to be absent. Apart from $\mathrm{CuO}$, these XRD spectra confirm the EDX analyses. It is not clear why the EDX analysis show an enrichment in $\mathrm{Cu}$ for samples $\mathrm{B}$ and $\mathrm{C}$, where XRD measurements show only a small amount of $\mathrm{CuO}$ to be present. One of the possibilities is the presence of $\mathrm{CuO}$ on samples $\mathrm{B}$ and $\mathrm{C}$ as an amorphous phase. For all three samples the c-axis length has been calculated from the peak position of the (007) peak. This results in $c=11.68 \pm 0.01 \AA$ for $A, c=11.69 \pm 0.01 \AA$ for $B$ and $c=11.71 \pm 0.01 \AA$ for $C$. According to Cava et al $/ 13 /$, the oxygen content $x$ can be deduced from the $c$-axis length to be $x=6.97 \pm 0.05$ for $A, x=6.92 \pm 0.05$ for $B$ and $x=6.77 \pm 0.05$ for $C$. From the same work it can be deduced that the transition temperature for $A$ and $B$ are expected to be around $90 \mathrm{~K}$, while $T_{c}$ for $\mathrm{C}$ should be around $60-80 \mathrm{~K}$. After storage in ambient air for 2 months $T_{c}$ measurements have been performed by a 4-point DC measurement. For both samples the resistances started 
to drop at temperatures below appr. $120 \mathrm{~K}$, but the noise in the signal was so large, that $T_{c}$ values could not be determined.

\section{4 - CONCLUSION}

$\mathrm{Ba}(\mathrm{hfa})_{2}$-tetraglyme has been proven to be an interesting novel barium precursor for the deposition of $\mathrm{Y}$ - $\mathrm{Ba}$-Cu-oxides. It is very volatile as compared to the commonly used $\mathrm{Ba}$ (thd) ${ }_{2}$, and thermally stable for prolonged periods of time, under the MOCVD conditions applied. $\mathrm{YBa}_{2} \mathrm{Cu}_{3} \mathrm{O}_{7-\delta}$ has been deposited at substrate temperatures of $800-900^{\circ} \mathrm{C}$. The hot-wall MOCVD reactor has been shown to be an inadequate system for the deposition of Y-Ba-Cuoxides. Continued experiments with $\mathrm{Ba}(\mathrm{hfa})_{2}$.tetraglyme and other novel $\mathrm{Ba}-\mathrm{Sr}$ - and $\mathrm{Ca}$ precursors are planned, in a cold wall stagnant flow reactor.

\section{5 - ACKNOWLEDGEMENT}

This research has been supported by the Dutch National Research Programme on High $\mathbf{T}_{c}$ Superconductors and by Asea Brown Boveri-Central Research in Heidelberg, Germany.

\section{6 - REFERENCES}

11/ Evets J.E., Moore D.F., J. R \& D. Ass. Future Electron Devices (Tokyo), in the press.

/2/ Schmaderer F., Huber R., Oetzmann H., Wahl G., Metall (Berlin), 44 (1990) p. 638-643.

13/ Berry A. D., Holm R.T., Fatemi M., Gaskill D.K., J. Mater. Res., 5 (1990) p. 1169-1175.

14/ Schmaderer F., Huber R., Oetzmann H., Wahl G., Appl. Surf. Science 46 (1990) p. 53-60.

15/ Zawadzki P.A., Tompa G.S., Norris P.E., Chern C.S., Caracciolo R., Kear B.H., Noh D.W., Gallois B., J. Electron. Mat., 19 (1990) p. 357-362.

16/ Watanabe K., Yamane H., Kurosawa H., Hirai T., Kobayashi N., Iwasaki H., Noto K., Muto Y., Appl. Phys. Lett., 54 (1989) p. 575-577.

17/ Netherlands Organization for Applied Scientific Research TNO, Netherlands Patent Appln. No. 8901507, European Patent Appln. No. 90201485.1, US Patent Appln. Nr. 5335391 and Japanese Patent Appln. Nr. 02156618, priority date 14/06/89.

18/ Spek A.L., Sluis P. van der, Timmer K., Meinema H.A., Acta Cryst., C46 (1990) p. 17411743.

19/ Malandrino G., Richeson D.S., Marks T.J., DeGroot D.C., Schindler J.L., Kannewurf C.R., Appl. Phys. Lett., 58 (1991) p. 182-184.

/10/ Zhang J.M., Wessels B.W., Richeson D.S., Marks T.J., DeGroot D.C., Kannewurf C.R., J. Apl. Physics., in the press.

/11/ Zouwen E. A. van der, Spee C.I.M.A. (unpublished results).

/12/ Yan M.F., Barns R.L., O’Bryan H.M., Gallagher P.K., Sherwood R.C., Jin S., Appl. Phys. Lett., 51 (1987) p. 532-534.

/13/ Cava R.J., Batlogg B., Chen C.H., Rietman E.A., Zahurak S.M., Werder D., Phys. Review B, 36 (1987) p. 5719-5722. 